\title{
Monetary Integration in East Asia: An Empirical Approach
}

\author{
José Brandão de Brito \\ Banco de Portugal and Technical University of Lisbon
}

\begin{abstract}
This paper investigates empirically the economic feasibility of monetary integration in East Asia. A structural VAR model is employed to decompose real output, real exchange rate and price level into a lagged polynomial of supply, demand and monetary shocks. The shocks are identified through the imposition of long-run restrictions, which are extracted from a version of Clarida and Gali's (1994) model extended in this paper to encompass the Balassa-Samuelson-effect. Once identified, the shocks are used to construct indicators relevant to monetary integration. Using the Euro-11 countries as benchmark, the overall results suggest that East Asian countries fulfil reasonably well the criteria looked at.
\end{abstract}

- JEL Classification: C32, F15, F40

- Keywords: Monetary integration, East Asia, optimum currency area, BalassaSamuelson effect, structural VAR, long run identifying assumptions

\section{Introduction}

The last decade has witnessed the proliferation of newly formed regional arrangements that in their diversity and reach contributed to forge closer economic regional co-operation and integration throughout the world. This emerging trend of regionalism begs, among others, the question of whether will East Asian countries step up the pace of economic integration and eventually engage in

*Corresponding address: Banco de Portugal, Research Department, Rua Francisco Ribeiro 2, 1150 Lisbon, Portugal. Tel: +351 213130 040. Fax: +351 213107 805. E-mail: jbrito@bportugal.pt. The views expressed in this paper are my own and not necessarily those of the Banco de Portugal. (C)2004-Center for International Economics, Sejong Institution, All Rights Reserved. 
monetary integration.

The academic debate on the economic merits of monetary integration in East Asia started with the influential contribution by Frankel (1991), in which the question of whether East Asia was a 'yen bloc' in the making was raised. The author argued that although the importance of the yen on the trade and financial flows of the region has been increasing, Japan is not necessarily pursuing a 'yen bloc' strategy for East Asia. Even if the kind of political constraints alluded to by Frankel are ignored, the formation of a 'yen bloc' has been hampered by the prominent presence of the US dollar among East Asian currency arrangements, as several countries keep one way or another a strong link to the American currency. It became clear from the outset of the debate that monetary integration in East Asia would be clouded by strategic-political issues and hindered by the bi-polar nature of the exchange rate regimes in the region.

Some of the literature that followed Frankel (1991) focused on the relative importance of the major international currencies in East Asia ${ }^{1}$ to show that the asymmetry with which the US dollar and the yen affect the different East Asian currencies imposes wide fluctuations between intra-regional currencies. Thus, as closer trade and financial links develop among East Asian economies the less appropriate the current divergent arrangements seem to be and so the more relevant the issue of monetary integration becomes. It is in this context that Eichengreen and Bayoumi (1996) hinted at the adoption of a common peg as a sensible way of avoiding the stresses created by systemic disparate movements among East Asian currencies. Goto and Hamada (1994) looked at the synchronisation of real shocks, degree of openness of the economies and degree of intra-regional factor mobility to find that based on those criteria a case can be made for the formation of a currency area in East Asia.

Having the increasing economic integration within East Asia and the regions seemingly unsuitable exchange rate arrangements as a background, the main objective of this paper is to draw on the optimum currency area theory ${ }^{2}$ to investigate empirically the economic feasibility of the formation of a currency area in East Asia. For that purpose the methodology advanced by Blanchard and Quah (1989) is applied to identify structural supply, demand and monetary shocks from the estimation of a

\footnotetext{
${ }^{1}$ See e.g. Benassy-Querre (1996).

${ }^{2}$ The whole analysis orbits around the symmetry of shocks among the countries candidates to form a currency union. Addressing all, often contradictory, extensive list of criteria of the optimum currency area theory is, naturally, unfeasible in the context of this work.
} 
reduced-form VAR model of the economy. This approach has the merit that it enables to unveil (some) crucial structural characteristics of the economies under study without explicitly resorting to detailed structural analytical models. All that is needed is a set of long run identifying restrictions. Once identified, the structural shocks are used to construct a host of indicators deemed relevant to the issue of monetary integration in East Asia. Those indicators include impulse-responses, correlation of shocks, speed of adjustment and the efficacy of the policy instruments in delivering stabilisation. The analysis is complemented with a similar exercise for the members of the Single European Currency as a means of providing a benchmark of monetary integration among sovereign states for the East Asian case.

Since the implementation of the Blanchard and Quah methodology requires long run identifying-restrictions, any analysis of the sort of the one conducted here needs a theoretical structural model that underpins the empirical study. For that purpose, the stochastic version of the IS-LM-Dornbusch model developed by Clarida and Gali (1994) is extended to encompass the Balassa-Samuelson-effect. The main motivation for such innovation ensues from Clarida and Galis model prediction that positive supply shocks induce a real depreciation and disinflation, which clearly contradicts the experience of several economies where fast productivity gains in the external sector are accompanied by a process of real appreciation and inflation that persists in the long run. As it will be demonstrated, the relevance of this extension is vindicated by the data on the East Asian countries under study.

The results of the empirical analysis suggest that, on balance, East Asian countries fulfil reasonably well the criteria looked at for monetary integration, at least in comparison with the Euro-zone members. Thus, assuming that there are significant benefits to be reaped from monetary integration and ignoring political considerations, the main findings of this paper imply that the creation of a currency area within East Asia might be economically desirable in the foreseeable future. The paper is structured as follows. Section II presents the theoretical model that underlies the empirical analysis and section III describes the empirical methodology and the data. Section IV analysis the results, whose main implications are collected in section IV in form of conclusion.

\section{Theoretical Framework}

The analytical framework that underpins the empirical application pursued in 
this paper builds on Clarida and Gali (1994), who use a stochastic version of the two-country, rational expectations open macro model developed by Obstfeld (1985). As highlighted by Clarida and Gali (1994), their model has a considerable strength in its ability not only to yield the typical IS-LM-Dornbusch results in the short run when price-adjustment is sluggish, but also to reproduce the features that characterise the equilibrium in the long run, when prices are assumed to fully adjust to shocks. However, the prediction of Clarida and Gali's model that in response to positive supply shocks the real exchange rate depreciates and the price level decreases, is at odds with the reality of some economies, in particular those endowed with a dynamic external sector exposed to international competition, where it is often the case that positive supply disturbances lead to real appreciation and inflation. This effect, known in the literature as the Balassa-Samuelson-effect after the seminal contributions by Balassa (1964) and Samuelson (1964) implies that asymmetric productivity shocks that raise the marginal product of labour by a greater extent in the external than in the internal sector of the economy, leads to an increase of the economy-wide wage rate that exceeds that of the economy-wide labour productivity, thereby generating price inflation and, ceteris paribus, real exchange rate appreciation.

In the context of Clarida and Galis (1994) model, encompassing the BalassaSamuelson-effect requires two changes to the basic setup. First, shocks to aggregate supply that hit the two sectors of the economy asymmetrically, by disturbing overall wages, affect the disposable income and, consequently, aggregate demand. Therefore, aggregate supply should be incorporated into the modelling of the IS equation. Second, if variations to total wages are accommodated by monetary authorities in the form of proportional adjustments in the money supply, as assumed, aggregate supply should list in the LM equation as well.

In what follows, all variables take on the usual meaning, have been subtracted of all deterministic components and with the exception of the interest rate are expressed in natural logarithms. All parameters are positive. The model consist of:

$$
\begin{aligned}
& y_{t}^{d}=d_{t}+\eta\left(s_{t}-p_{t}\right)-\sigma\left[i_{t}-E_{t}\left(p_{t+1}-p_{t}\right)\right]+\beta_{t} y_{t}^{s} \\
& p_{t}=(1-\theta) E_{t-1} p_{t}^{e}+\theta p_{t}^{e} \\
& m_{t}^{s}+\alpha_{t} y_{t}^{s}-p_{t}=y_{t}-\lambda i_{t} \\
& i_{t}=E_{t}\left(s_{t+1}-s_{t}\right)
\end{aligned}
$$


where, as in Clarida and Gali's (1994), the dynamic behaviour of output supply $\left(y_{t}^{s}\right)$, absorption $\left(d_{t}\right)$ and money $\left(m_{t}\right)$ is given by:

$$
\begin{aligned}
& y_{t}^{s}=y_{t-1}^{s}+z_{t} \\
& d_{t}=d_{t-1}+\delta_{t}-\gamma \delta_{t-1} \\
& m_{t}=m_{t-1}+v_{t}
\end{aligned}
$$

and $z_{t}, \delta_{t}$ and $v_{t}$ are i.i.d. white-noises denoting supply shocks, demand shocks and monetary shocks, respectively. As apparent from (5), supply and money shocks have permanent effects, whereas demand shocks have both permanent and temporary effects.

Equation (1) is a stochastic version of a typical IS curve extended to incorporate the Balassa-Samuelson effect. The last term on the right-hand side of (1) accounts for the effect of accumulated supply shocks on disposable income, which is naturally positive and quite possibly greater than one if the impact of supply shocks on output demanded exceeds that on output supplied. The parameter $\beta_{\mathrm{t}}$ can be greater than one if the accumulated impact of supply shocks on demand exceeds that on supply, but its precise value is determined exogenously by the sequence of the supply shocks hitting the economy until time $t$. Equation (2) delivers the models pricing rule according to which the price level is given by a weighted average of the market-clearing price expected in period $t-1$ to prevail in period $t, E_{t-1} p_{t}^{e}$ and the price that after adjustment to all shocks hitting the system in $t$ actually clear the output market, $p_{t}^{e}$. The parameter $\theta$ indexes price-flexibility. The money-market equilibrium is described by a stochastic version of the LM equation (3) modified to include the assumed policy-rule of accommodation to variations in total wages brought about by asymmetric productivity shocks. The parameter $\alpha_{t}$ measures the response of relative money supply to accumulated relative supply shocks via changes in relative total wages. The parameter $\alpha_{t}$ is positive and as with $\beta_{t}$, the time path of $\alpha_{t}$ is exogenously determined by the sequence of the supply shocks. The assets-market equilibrium is given by the interest parity condition in equation (4).

\section{A. Long Run Equilibrium}

The long run is here characterised by the behaviour of variables when flexible prices prevail, rational expectations apply and output is supply-determined. Hereafter, the superscript $e$ denotes the value of variables in the long run. The long 
run equilibrium for the real exchange rate, $q_{t}^{e}$, is found by equating the supply of output to aggregate demand and inserting (4) into (1). Setting $\theta=1$, gives:

$$
q_{t}^{e}=\frac{\left(1-\beta_{t}\right) y_{t}^{s}-d_{t}}{\eta}+(\eta(\eta+\sigma))^{-1} \sigma \gamma \delta_{t}
$$

Substituting $i_{t}$ in (3) for (4) and using (6) yields the equilibrium solution for the price level:

$$
p_{t}^{e}=m_{t}+\left(\alpha_{1}-1\right) y_{t}^{s}+\lambda(1+\lambda)^{-1}(\eta+\sigma)^{-1} \gamma \delta_{t}
$$

The long run equilibrium is described by equations (6) and (7) and $y_{t}=y_{t}^{s}$. All the basic long run properties of the IS-LM-Dornbusch family, including long run neutrality, are present in the model above. However, two extra effects spring out from this particular setup. As for the real exchange rate, the net effect of supply shocks is ambiguous and depends on the magnitude of $\beta_{t}$. Specifically, whenever the impact of the increased disposable income pertaining to the wage rise that follows an asymmetric supply shock is sufficiently strong, the real exchange rate appreciates with supply shocks, as the Balassa-Samuelson-effect would suggest. Similarly, if the effect of supply shocks on money supply via increased total wages, as given by $\alpha_{t}$, outweighs the increment on transactions demand for money brought along by the rise of output supply, prices increase with supply shocks.

It turns out that by making supply shocks influence aggregate demand and the supply of money, we have replicated the Balassa-Samuelson-effect, since the sign of the long run impact of supply shocks on the real exchange rate and price level is ambiguous and depends on the strength of the productivity shocks hitting the external sector of the economy.

Moreover, notice that the long run solution is triangular as output is solely determined by supply shocks, the real exchange rate is driven by both supply and demand shocks, while the price level responds to all three shocks. It is this triangular form that provides the three long run identifying-restrictions needed for the econometric application to the analysis of monetary integration in East Asia. These restrictions are thus, that both demand and monetary shocks have no permanent effect on output and also that monetary shocks do not influence the long run level of the real exchange rate. 


\section{B. Short Run Equilibrium}

The next step consists of deriving the equations that define the equilibrium in the short run. That is defined as the equilibrium at which the variables settle when sluggish price-adjustment instead of flexible-price applies. We start by looking at the short run solution for the price level by plugging (7) into equation (2) and making use of (5), which yields:

$$
p_{t}=p_{t}^{e}-(1-\theta)\left[v_{t}+\left(\alpha_{t}-1\right) z_{t}+\lambda(1+\lambda)^{-1}(\eta+\sigma)^{-1} \gamma \delta_{t}\right]
$$

The expression for the equilibrium real exchange rate in the short run is derived by inserting (1) and (4) into (3) and using (8), as follows:

$$
q_{t}=q_{t}^{e}+(1+\lambda)(\lambda+\eta+\sigma)^{-1}(1-\theta)\left[v_{t}+\left(\alpha_{t}-1\right) z_{t}+\lambda(1+\lambda)^{-1}(\eta+\sigma)^{-1} \gamma \delta_{t}\right]
$$

The demand-determined level of output is obtained by plugging (9) into (1) to obtain:

$$
\begin{array}{r}
y_{t}=y_{t}^{s}+(\eta+\sigma)(1+\lambda)(\lambda+\eta+\sigma)^{-1}(1-\theta) \\
{\left[v_{t}+\left(\alpha_{t}-1\right) z_{t}+\lambda(1+\lambda)^{-1}(\eta+\sigma)^{-1} \gamma \delta_{t}\right]}
\end{array}
$$

Together, equations (8)-(10) define the short run equilibrium. From those equations, it is apparent that the sluggishness of price adjustment dampens the impact of the various shocks on the price level relative to the flexible-price setting. The Keynesian-like outcome stems from price-sluggishness in the short run dictating the impact of shocks to be distributed between nominal and real variables. As with the long run equilibrium, positive demand and monetary shocks affect output positively in the short run. In addition, the Dornbusch (1976) 'overshooting' result by which a positive monetary shock depreciates the real exchange rate by a greater extent in the short than in the long run, is also replicated. But the novelty that results from the introduction of the BalassaSamuelson effect in this setup pertains to the supply shocks. In the absence of such effect, a positive supply shock would stimulate output, but by less than in the long run, since in the short run prices do not fully-adjust downwards and so demand does not increase by as much as in the long run. However, if supply shocks affect 
disposable income via wages as assumed in this model, then the level of output in the short run relative to that in the long run is undefined a priori, but depends on whether $\alpha_{\mathrm{t}}$ is smaller or greater than one.

In the short run all variables react to every shock and equilibrium is not triangular, implying that sluggish price adjustment bring all structural disturbances into play in the short run dynamics of all variables, in contrast with the long run outcome.

It is still worth noting that the innovation introduced in this paper by which supply shocks have an impact on aggregate demand, paints a different picture to that of Clarida and Gali (1994), bringing greater generality to the stochastic IS-LMDornbusch framework. In particular, it generates richer dynamics in what concerns the macro variables' response to supply shocks in that, depending on the specific characteristics of the economies, the sign of the impact of supply shocks on the endogenous variables rest on the values of $\beta_{t}$ and $\alpha_{t}$. Finally, apart from any outright interest, the model serves the main purpose of furnishing a theoretical framework upon which the empirical inquiry into the feasibility of the creation of a currency area within East Asia that follows is drawn. The features of the long run equilibrium provide the long run restrictions required by the methodology put forward by Blanchard and Quah (1989) for the estimation of not only the supply, demand and monetary structural disturbances, but also of the magnitude of their impact on output, real exchange rate and price level. In addition, both short and long run equilibria provide the so-called over-identifying restrictions, which prove useful in gauging the appropriateness of the model in light of the empirical results.

\section{Empirical Framework}

\section{A. Identification}

We start by assuming that the vector of the first-differences of the endogenous variables, $X \equiv\left[\Delta y_{t} ; \Delta(s-p)_{t} ; \Delta p_{t}\right]$ is covariance-stationary, has been de-meaned and de-trended and can be expressed as a linear combination of current and lagged structural shocks such that:

$$
\begin{aligned}
& X_{t}=C_{0} u_{t}+C_{1} u_{t-1}+\ldots \text { or } X=C(L) u \text { and } \\
& \operatorname{Var}(u)=E\left(u u^{\prime}\right)=I
\end{aligned}
$$


where $u \equiv\left[u_{s} ; u_{d} ; u_{m}\right]$ is a vector of independent and serially uncorrelated structural supply, demand and monetary disturbances, respectively, and $C(L) \equiv C(L)_{i j}$ for $i, j$ $=1,2,3$, where $i$ indexes the endogenous variables and $j$ the structural shocks, is a $3 \times 3$ matrix of lagged polynomials to be estimated. Since the disturbances are independent of each other, their variance-covariance matrix is diagonal and so the assumption that the variance-covariance of the structural shocks is the identity matrix is a harmless simplification. Since the vector of structural disturbances, EMBED Equation $\dot{u}$, is unobservable the system of equations in (11) cannot be estimated directly and information on this system must be retrieved from elsewhere. More precisely, the methodology developed by Blanchard and Quah (1989) is used to identify the structural system in (11) from the estimates of a VAR on the vector $X$. Bearing on the model developed in section 2, the three identifying-restrictions used to implement the identification procedure read as follows. In the long run, neither demand nor monetary shocks affect output, and also, monetary shocks do not affect the real exchange rate.

At this stage, it is worth mentioning that, while the estimated reduced-form VAR has as many variables as identifiable structural shocks, one cannot guaranteed it to be exempt from the omitted variables bias problem. Moreover, it must be stressed that any policy implications taken from the VAR results can be plagued by the Lucas critique, a risk one always run endure in this type of analysis.

\section{B. The Data}

\section{Data Description}

For the empirical analysis that follows, real output was proxied with gross domestic product (GDP) at constant prices, the price level by the consumer price index and whenever possible the real exchange rate for each country was proxied by the effective real exchange rate index ${ }^{3}$. In practice, the availability of an effective exchange rate index determined the number of East Asian countries included in the panel. The panel comprises the Euro-11 countries with the exception of Luxembourg (due to data limitations) and a sample of six East Asian countries constituted by Hong Kong, Japan, Korea, Malaysia, Philippines and

\footnotetext{
${ }^{3}$ For Hong Kong and Singapore an effective real exchange rate index could not be found in any of the supra-national and domestic statistical sources scrutinised, which meant that a proxy had to be built from an effective nominal exchange rate index and a domestic price index.
} 
Singapore. In order to have any meaningful sample of East Asian countries ${ }^{4}$ the data frequency was forced to be annual. The series for the three variables for all countries in the panel were drawn from the International Financial Statistics of the International Monetary Fund, unless unavailable. For an exact description of the sources of each series refer to table 1 . The time span covered by the series wonders around the 1979-1998 period, although the specific starting and ending date for each country ultimately depends on the common availability of the series (see table 1). Finally, all series were logarithmised.

\section{Testing for the Order of Integration}

For a correct implementation of the present methodology it is crucial that all variables included in the VAR estimation are stationary. Since the eventual nonstationarity of the data can be attributed to the presence of either stochastic or deterministic trends, or both, it is important to use a testing procedure that discloses the sources of non-stationarity in the data so that it can be properly transformed for the VAR estimation. To tackle this matter, the sequential testing procedure advocated by Ayat and Burridge (2000) was adopted ${ }^{5}$. An essential

Table 1. Data Sources

\begin{tabular}{|c|c|c|c|c|c|c|c|}
\hline & \multicolumn{2}{|c|}{ Real Output } & \multicolumn{2}{|c|}{ Real Exchange Rate } & \multicolumn{2}{|c|}{ Real Price Level } & \multirow[b]{2}{*}{ Span } \\
\hline & Series & Source & Series & Source & Series & Source & \\
\hline Austria & GDP at constant prices & IFS/IMF & Real effective ex. rate & IFS/IMF & Consumer price index & IFS/IMF & $1979-98$ \\
\hline Belgium & GDP at constant prices & IFS/IMF & Real effective ex. rate & IFS/IMF & Consumer price index & IFS/IMF & $1979-97$ \\
\hline Finland & GDP at constant prices & IFS/IMF & Real effective ex. rate & IFS/IMF & Consumer price index & IFS/IMF & $1979-97$ \\
\hline France & GDP at constant prices & IFS/IMF & Real effective ex. rate & IFS/IMF & Consumer price index & IFS/IMF & $1980-98$ \\
\hline Germany & GDP at constant prices & IFS/IMF & Real effective ex. rate & IFS/IMF & Consumer price index & IFS/IMF & $1979-98$ \\
\hline Hong Kong & GDP at constant prices & CSDHK & $\mathrm{a}$ & HKMDS & Consumer price index & HKMDS & $1978-98$ \\
\hline Ireland & GDP at constant prices & IFS/IMF & Real effective ex. rate & IFS/IMF & Consumer price index & $\mathrm{CSO}$ & $1979-97$ \\
\hline Italy & GDP at constant prices & IFS/IMF & Real effective ex. rate & IFS/IMF & Consumer price index & IFS/IMF & $1980-97$ \\
\hline Japan & GDP at constant prices & IFS/IMF & Real effective ex. rate & IFS/IMF & Consumer price index & IFS/IMF & $1980-98$ \\
\hline Korea & GDP at constant prices & IFS/IMF & Real effective ex. rate & OECD Statistics & Consumer price index & IFS/IMF & $1980-97$ \\
\hline Malaysia & GDP at constant prices & IFS/IMF & Real effective ex. rate & IFS/IMF & Consumer price index & IFS/IMF & $1979-97$ \\
\hline Netherlands & GDP at constant prices & CBS & Real effective ex. rate & IFS/IMF & Consumer price index & IFS/IMF & $1979-98$ \\
\hline Philippines & GDP at constant prices & IFS/IMF & Real effective ex. rate & IFS/IMF & Consumer price index & IFS/IMF & $1981-98$ \\
\hline Portugal & GDP at constant prices & IFS/IMF & Real effective ex. rate & IFS/IMF & Consumer price index & IFS/IMF & $1979-97$ \\
\hline Singapore & GDP at constant prices & IFS/IMF & $\mathrm{a}$ & IFS/IMF & Consumer price index & IFS/IMF & $1979-98$ \\
\hline Spain & GDP at constant prices & IFS/IMF & Real effective ex. rate & IFS/IMF & Consumer price index & IFS/IMF & $1980-98$ \\
\hline
\end{tabular}

a- Series created from nominal effectuve exchange rate index and consumer price index.

CBS- Centraal Bureau voor de Statistiek, Netherlands

CSDHK- Census and Statistics Department of Hong Kong

CSO- Central Statistics Office, Ireland

HKMDS- Hong Kong Monthly Digest of Sttistics

${ }^{4}$ An extended sample of East Asian countries was unavailable due to lack of data on effective exchange rates.

${ }^{5}$ For a description of the steps involved in the sequential procedure as well as the correspondent test equations and critical values see Ayat and Burridge (2000, p.74-78 and appendix). 
feature of this sequential procedure is that by pre-testing for a unit root, it allows the tests for the deterministic components to be conducted in levels or firstdifferences (depending on the results of the pre-test) such that the sampling distribution of the t-statistic under the null hypothesis is the t-distribution and so the standard critical values are applicable. Moreover, this procedure provides a Dickey-Fuller-Generalised Least Squares (DF-GLS) test (and respective critical values) for the presence of a quadratic trend. The results of the unit root tests reveal that real output, real exchange rate and price level all contain a unit root in all countries in the panel, although the degree of the trend polynomial varied across countries and variables. The possibility that the series may be I(2) was tested using Augmented Dickey-Fuller tests on the first-differenced and detrended series and was uniformly rejected for all variables in all countries.

\section{Principal Component Analysis}

As a first approach to the enquiry into the economic feasibility of monetary integration in East Asia, the principal component analysis is employed to convey a multi-variable measure of correlation of the change in each of the variables, real output, real exchange rate and price level across the six East Asian countries and also across the Euro-members for comparison. The higher the percentage of the total variance of the changes in the real output, real exchange rate and price level pertaining to a group of countries that is accounted for the first principal component, the higher should be the degree of integration among those countries.

Table 2 presents the estimated shares of the total variance of each of the variables explained by the first principal component across three blocks of countries. The first block encompasses the six East Asian countries, the subject of this study, the second includes the Euro-11 members, the benchmark case of recent currency unification among sovereign states and the third consists of a control group. The results are reported for the full period covered by the sample and are also brokendown into two sub-periods, roughly covering the 1980s and the 1990s, respectively.

For the full period, the share of the total variance of real output growth explained by the first principal component is 48 per cent in East Asia and 51.5 per cent in the Euro-11. The failure to discern a significant difference in the coherence of real output variations between the East Asian and Euro-11 blocks associated with a higher correlation found for the control group, indicates that when the full sample is considered, output growth is not exceptionally synchronised in either 
Table 2. Share of Variance Explained by the First Principal Component

\begin{tabular}{l|ccc}
\hline & East Asia & Euro-Zone & Control Group \\
\hline & & Real Output Growth \\
Full Period & 0.4804 & 0.5146 & 0.5973 \\
$1981-1989$ & 0.5184 & 0.5479 & 0.6642 \\
$1990-1997$ & 0.5028 & 0.7769 & 0.7438 \\
& & & \\
& & Real Exchange Rate Variation & \\
Full Period & 0.6263 & 0.3631 & 0.5785 \\
$1981-1989$ & 0.6995 & 0.4959 & 0.5799 \\
$1990-1997$ & 0.6486 & 0.4803 & 0.6821 \\
& & & \\
& & & \\
Full Period & & & \\
$1981-1989$ & 0.8584 & 0.8725 & 0.7036 \\
$1990-1997$ & 0.8889 & 0.8704 & 0.7863 \\
\end{tabular}

Note: The control group comprises the United States, Germany, Japan, Canada, Australia and Switzerland

group of countries. However, the analysis of the sub-periods unveils a remarkable process of business-cycles convergence in the Euro-11 during the 1990s, which is presumably reflecting the effects of the creation of the Single Market in Europe and other steps towards closer economic integration.

The movements of the real exchange rate are significantly more coherent across East Asian countries than across the Euro-zone countries regardless of the sample partition one chooses to analyse. Also, the change in the real exchange rate is more strongly correlated in East Asia than in the control group for the whole sample and for the sub-period covering the 1980s. An important feature of these results is that, as far as exchange rate stability is concerned, East Asia detains a 'natural' comparative advantage for currency unification relatively to Europe. This 'natural' comparative advantage ensues from the fact that while exchange rate stability has been the backbone of the individual macroeconomic strategies pursued by most of the East Asian countries for some time, in Europe, exchange rate stability has been a rocky and eventful journey.

Based on the share of inflation's total variance explained by the first principal component, price movements are highly correlated across East Asia, Europe and also the control group for the whole period. These results reflect the widespread trend of disinflation that has been occurring since the early 1980s. Nevertheless, it is worth noting that there is a greater degree of synchronisation in East Asia and the Euro-11 than it is the case for the control group. This level of inflation 
convergence, by facilitating the implementation of a unified monetary policy, constitutes a distinctive advantage for monetary integration in these two blocks.

The above exploratory analysis of the raw data on the two blocks of countries serves the main purpose of giving an initial flavour into the economic feasibility of monetary integration in East Asia. The principal component analysis conducted suggests that, if anything, exchange rate and price variations are more correlated across East Asian countries than in the Euro-zone. Noting that exchange rate and inflation convergence were two of the cornerstone pre-conditions for joining the European Single Currency and that East Asian countries outperform the Eurozone on this score, the hypothesis that the economic conditions for monetary integration within East Asia are laid down, at least in comparison with the European experience, is advanced.

\section{Empirical Results}

The aim of this section is use the identified auto-regressive coefficients and disturbances of the structural model presented in equation (11) to construct indicators deemed relevant to evaluate the feasibility of monetary integration in East Asia.

\section{A. Impulse-Responses}

In the present analysis, the impulse-response functions give the time profile of the impact of each structural shock on the level of each endogenous variable. Once estimated, the impulse-response coefficients serve the purpose of assessing the degree of similarity of the pattern of responses to disturbances across the East Asian countries under study. If an overall pattern of qualitatively and quantitatively synchronised responses emerges from the data, it must be the case that the costs inherent to monetary unification are smaller than otherwise. The estimation of the impulse-response serves the additional purpose of testing the validity of the modified version of the stochastic IS-LM-Dornbusch framework developed in section II.

Reduced-form VARs comprising the first differences of real output, real exchange rate and the price level were estimated by $\mathrm{OLS}^{6}$ for Hong Kong, Japan,

\footnotetext{
${ }^{6}$ The OLS estimator is consistent and efficient since in this case it yields the same estimates as the maximum likelihood estimator. Note that, even though the errors are correlated across equations (as they are linear combinations of the structural shocks), the method of seemingly unrelated regressions does not add to the efficiency of the estimation procedure since the three equations in the VAR have identical right-hand side variables.
} 
Korea, Malaysia, Philippines and Singapore. The VAR is estimated with a constant term for each equation of the system and the number of lags was uniformly set equal to two in order to preserve the symmetry of specification across the six economies, as the optimal lag found through the Schwartz Bayesian information criterion varied between one and two for the countries in the panel. Finally, the impulse-response coefficients contained in the matrix $C(L)$ in equation (11) and for that matter the structural disturbances, were identified from the reduced-form VARs estimates through the Blanchard and Quah methodology.

The impulse-response coefficients were estimated for a range of twelve years for the six East Asian countries included in the data set. The obtained impulseresponse coefficients measure the dynamic response of a one-standard deviation of a particular shock on a given endogenous variable. In figures 1-9 (in appendix) the plots of the estimated impulse-response coefficients for a twelve-year time span are presented for each shock, variable and country under analysis. The three different shocks considered yield nine separate effects on the three endogenous variables, of which seven are given an unambiguous sign by the over identifyingrestrictions. As six countries are being analysed, forty-two signs must be compared against the predictions of the model. In general, the estimation results are in accordance with the model of section II. As it can be observed from figures 1-9, only

\section{Figure 1.}
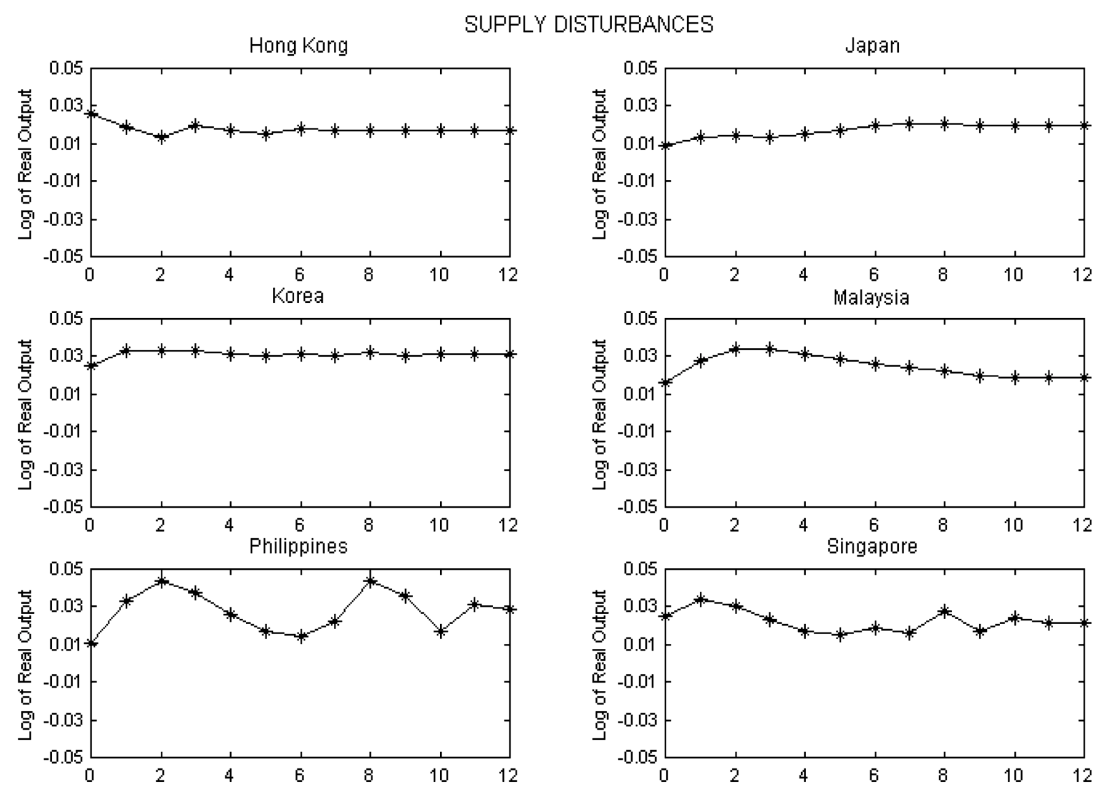
five out of the forty-two signs do not conform with the over-identifying restrictions, which constitutes a quite satisfactory ratio in face of the inevitable problems associated with data accuracy, sample sizes and estimation procedures. Therefore, the results based on the data of these East Asian countries lend considerable support to the model presented.

\section{Real Output Responses}

The general pattern of the real output response to supply disturbances conforms to the predictions of the model and is characterised by a short run reaction that outstrips the long run effect, followed by a gentle downward convergence towards the long run level. The exception to this behaviour is found in Japan where the initial impact is somewhat subdued, but as one moves along the time-horizon, the effect of supply shocks increases steadily towards the long run level. Overall, the shape and magnitude of the responses of real output to supply disturbances overtime are reasonably similar across the East Asian countries in the panel.

The imposition of the identifying restriction that demand shocks have no long run effect on real output is plainly illustrated by the fact that the output responses plotted in figure 2 converge towards zero in all countries. The over-identifying restrictions according to which demand disturbances exert a short-term positive

Figure 2.
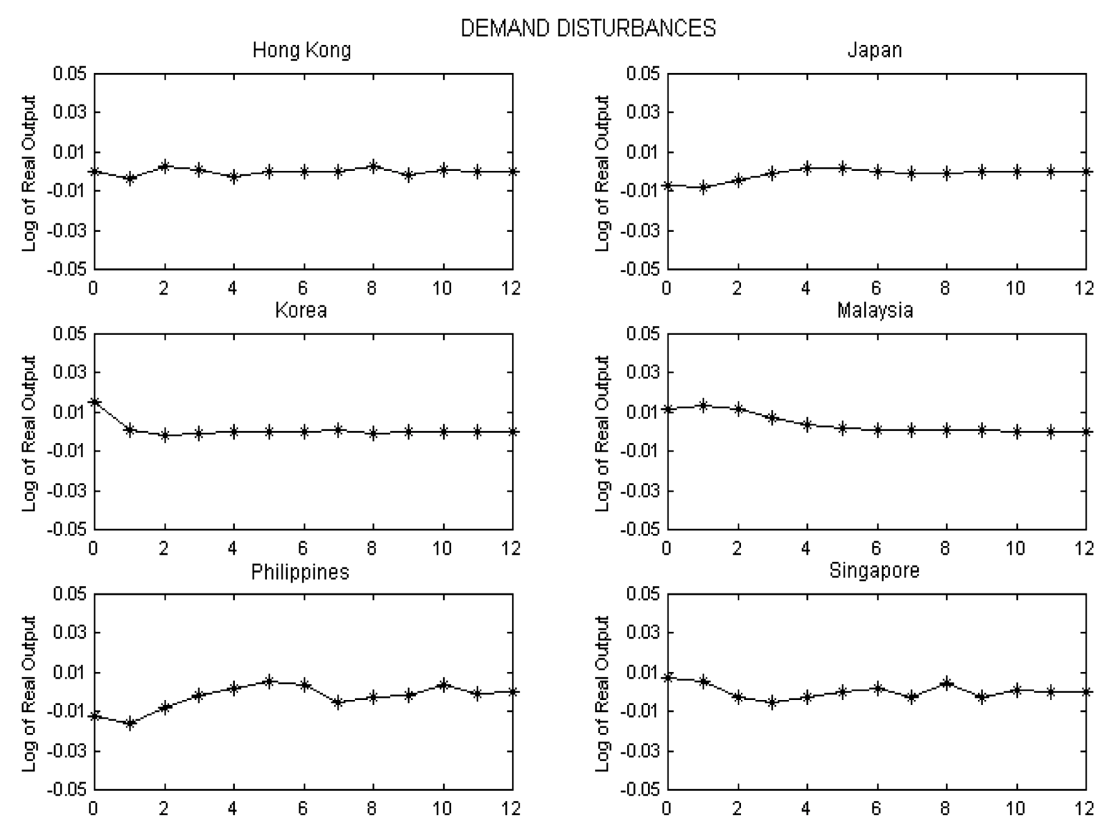
impact on real output is satisfied in Korea, Malaysia and Singapore. In these countries, the real output responses exhibit the hump-shape implied by the combination of the identifying and over-identifying restrictions. For the remaining three economies, the short-term real output response to demand shocks is perverse as some of the impulse-response coefficients meander in negative territory. In spite of the qualitative patterns of response differing across countries, the quantitative divergence is relatively small, as the short-term impulse-response coefficients always fall into the $-1 \%$ to $1 \%$ interval ${ }^{7}$.

As patent in figure 3, monetary disturbances have a hump-shaped effect on real output of all countries under analysis, with the possible exception of Singapore. Such shape follows the predictions of the underlying model, whose identifying and over identifying-restrictions impose the positive effects of monetary shocks on real output to be temporary. On the whole, the sequences of real output responses to monetary disturbances are fairly kindred among the sample of East Asian countries used here.

Figure 3.
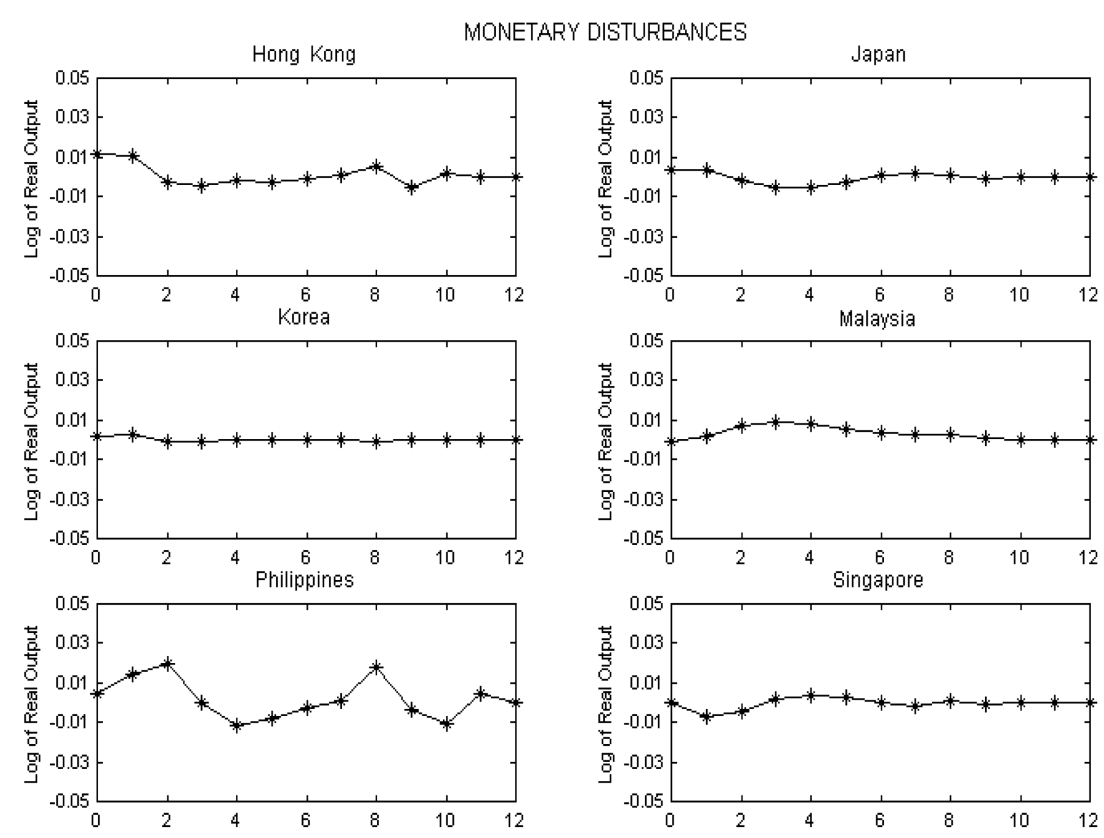

\footnotetext{
${ }^{7}$ Since real output is expressed is logarithms, an impulse-response coefficient of 0.01 means that real output increases $1 \%$ with a one-standard deviation supply shock.
} 


\section{Real Exchange Rate Responses}

The innovation introduced in the IS-LM-Dornbusch framework of section II by which positive supply shocks boost aggregate demand, implies that impulseresponse coefficients are not subject to any theoretical sign restrictions, as the response rests on the magnitude of the parameters $\alpha_{t}$ and $\beta_{t}$ in each economy. Figure 4 shows that for all countries with the exception of South Korea, supply disturbances lead to an appreciation ${ }^{8}$ of the real exchange rate in the long run. Such outcome is hardly surprising in face of the fact that the East Asian economies have adopted an export-driven growth strategy, which makes it quite plausible that productivity gains occur at a faster pace in the external sector than in the internal sector of the economy. If that is the case, the likelihood that the impact of supply disturbances on aggregate demand exceeds that on aggregate supply, as implied by the Balassa-Samuelson effect, is greater. The general pattern is characterised by a steady appreciation in the short-term that slightly overshoots the long run level, followed by a gradual decline of the response coefficients towards the long run impact. The similarity of the shapes of response to supply shocks among all

Figure 4.
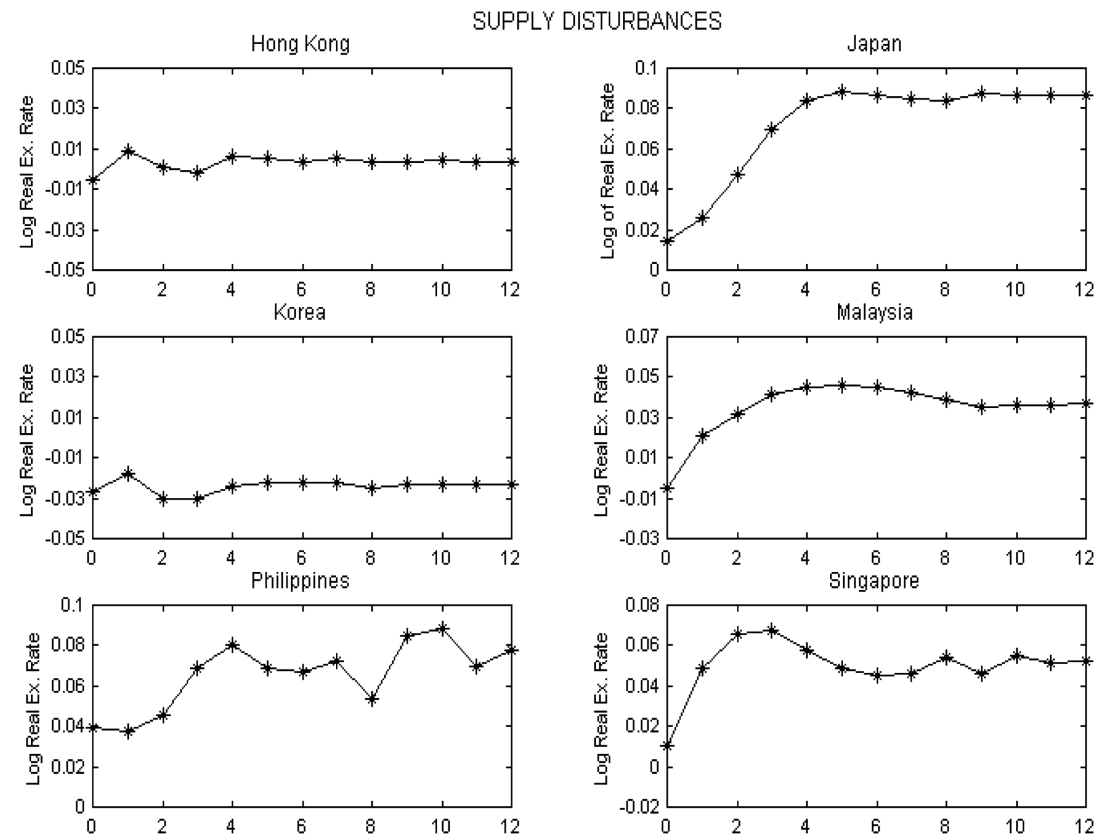

${ }^{8}$ Contrary to the way the real exchange rate was defined in the model of section 2 , for this empirical application an appreciation is denoted by an increase in the value of the variable. 
countries but South Korea, in spite of the varying magnitudes of adjustment, signals that the cost for these countries of relinquishing control over the nominal exchange rate should be, ceteris paribus, relatively small.

The results on the impact of structural demand shocks on the real exchange rate are illustrated in figure 5. The response dynamics estimated for the six East Asian countries fit remarkably close to the predictions of the model developed in section II. Indeed, in all cases a positive demand shock is followed by a real appreciation that lingers on towards the long run. In most countries the short run reaction overshoots the long run impact, a result also accommodated by the model. Again, the response pattern to demand shocks across the countries considered is fairly similar, even though the magnitudes of adjustment are somewhat more heterogeneous.

The imposed identifying restriction that monetary shocks do not affect the long run level of the real exchange rate is clearly visible in figure 6 , as the impulseresponse coefficients in all countries converge to zero. Figure 6 also shows that the responses match the predictions of the analytical model by which shocks to money produce a temporary real exchange rate depreciation. The combination of the long run identifying restrictions and the short-term over-identifying restrictions define a pattern that emulates Dornbuschs "overshooting" result. The only exception to

Figure 5.

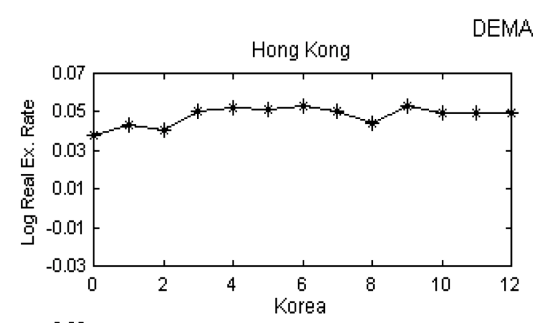

DEMAND DISTURBANCES
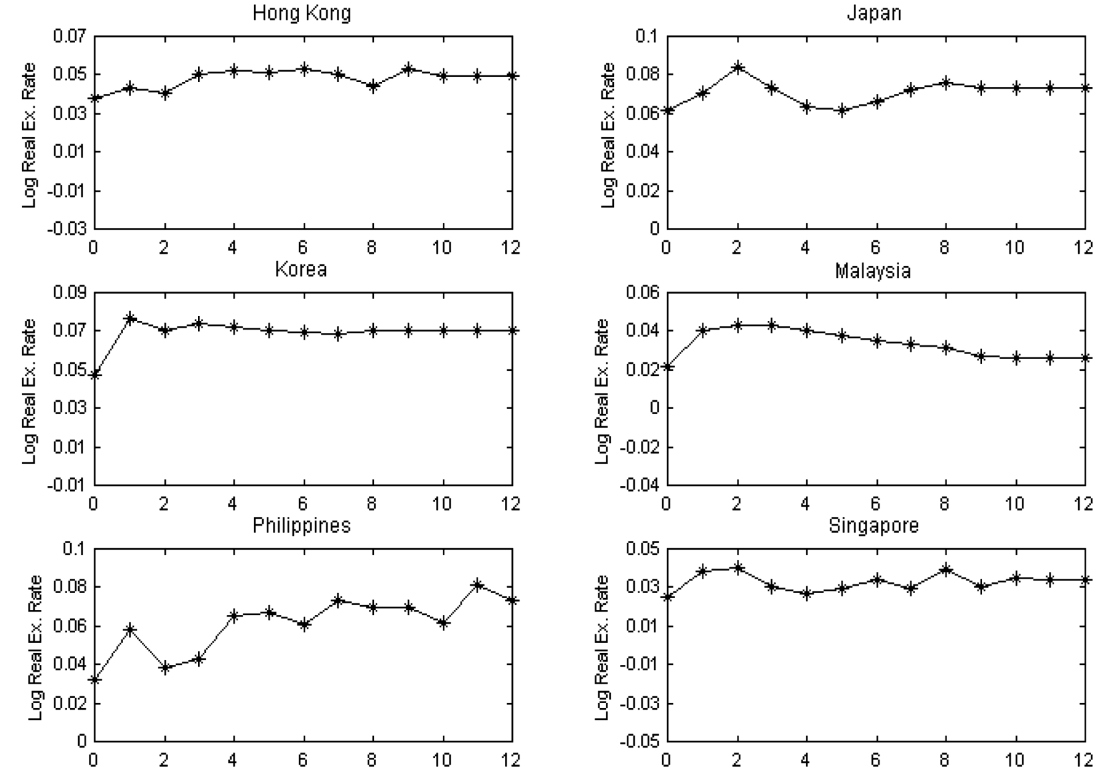
Figure 6.
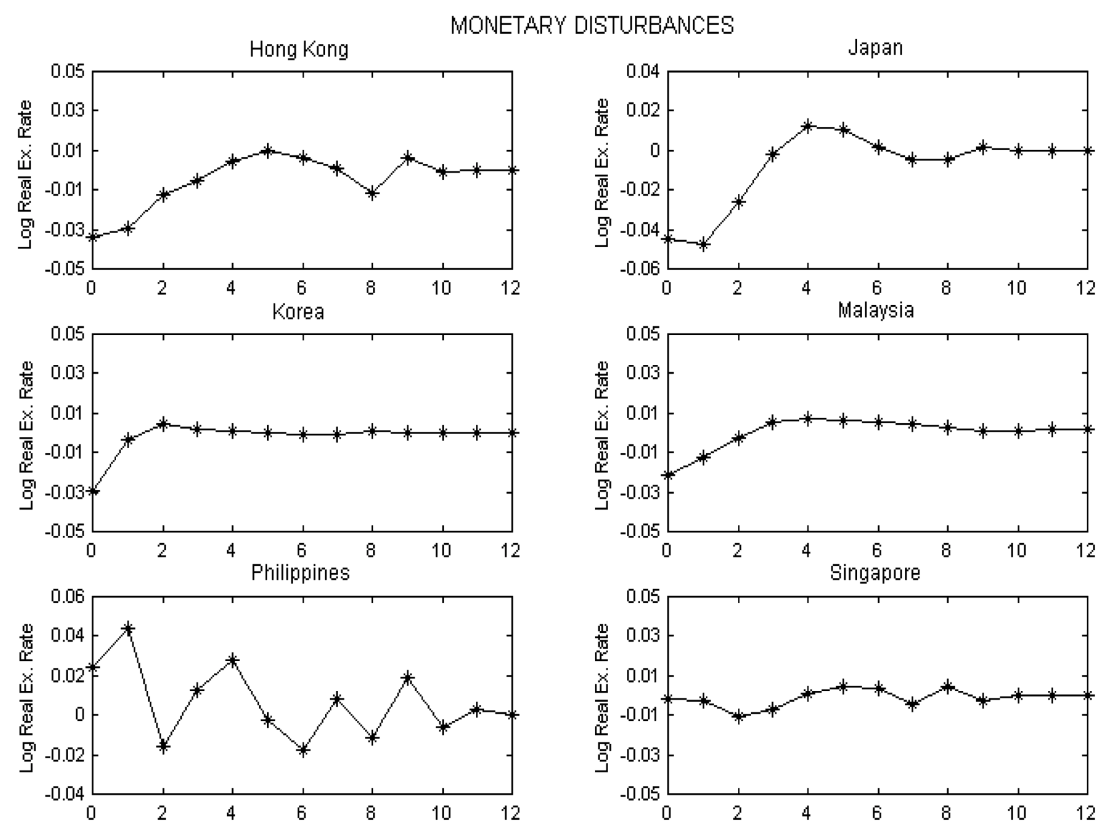

this pattern occurs in the Philippines where the response is saw teeth-shaped.

\section{Price Level Responses}

The consideration of the Balassa-Samuelson effect for the model developed earlier implies that the impact of supply shocks on prices is ambiguous, as it rests on the magnitude of the parameter $\alpha_{t}$ in equation (3). Figures 5 and 7 paint a coherent picture in all countries but the Philippines: when supply shocks create price inflation (deflation) such shocks also lead to real exchange rate appreciation (depreciation). Such outcome only reinforces the hypothesis postulated in the present work that the Balassa-Samuelson effect has a bearing on the way economies adjust to supply shocks. However, since the impact throughout the whole time-horizon of supply shocks on the price level is quite minute (between $0 \%$ and $1 \%$ ), it seems that the Balassa-Samuelson-effect is relatively more preponderant in the output market than in the money market ${ }^{9}$.

Figure 8 presents the price level dynamic response to demand disturbances. As expected and in accordance with the theoretical model of section II, demand shocks induce an increase in the price level that is more accentuated in the long

${ }^{9}$ Referring to the model, that implies that the parameter $\beta_{t}$ exceeds $\alpha_{t}$ in size. 
Figure 7.
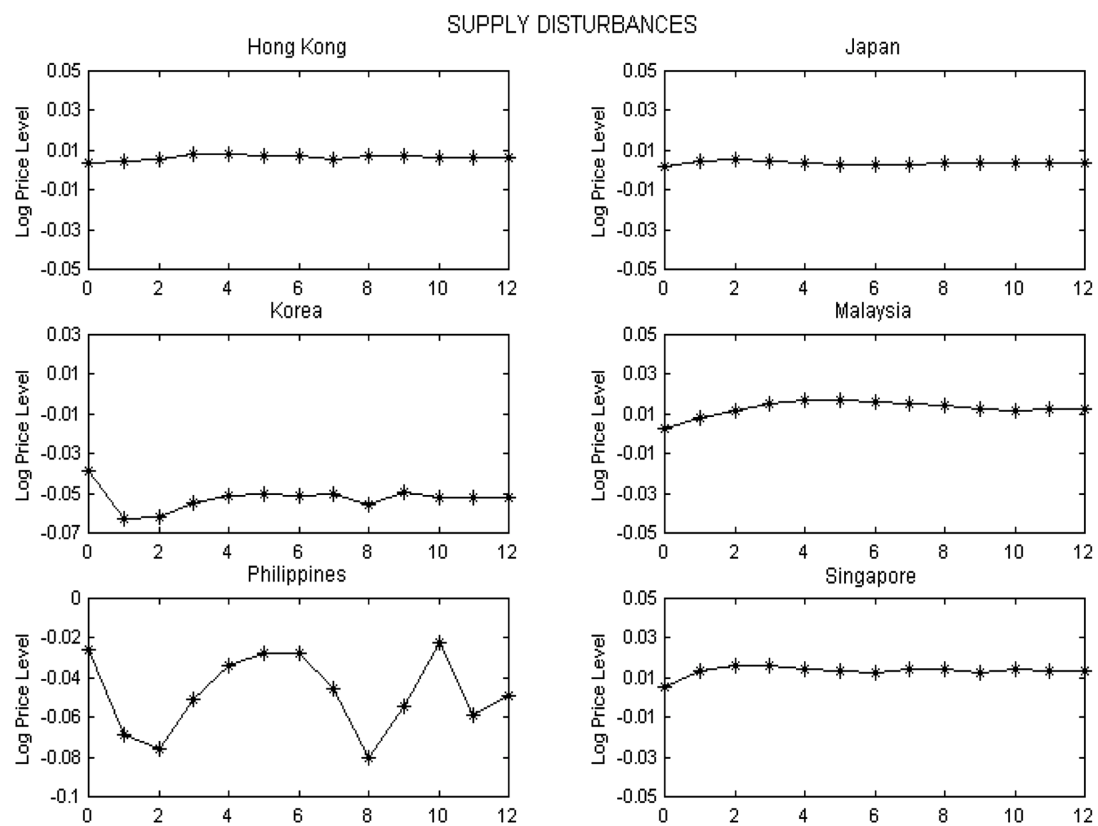

Figure 8.
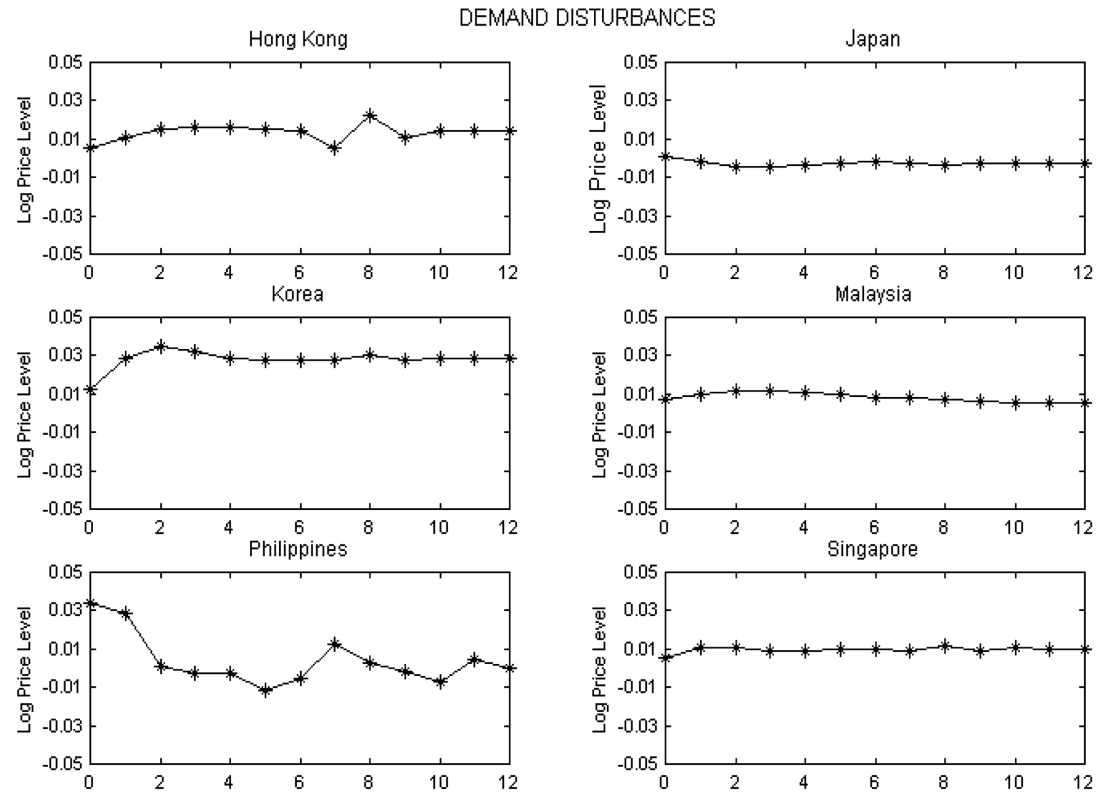

than in the short run in all countries except Japan and Philippines. The magnitude of the responses is quite similar across the board. 
Figure 9 shows the results for the price level response to structural monetary disturbances. Both short and long run predictions of the model are satisfied by the data on the six East Asian countries. Indeed, figure 9 corroborates the existence of a positive relation between the occurrence of monetary shocks and price inflation whatever time scale is picked. Moreover, with the exception of the Philippines, the long run response exceeds the initial impact, which in the light of the theoretical framework used here is driven by the duality existing between price adjustment in the short and long terms. The overall pattern is quite analogous across the countries.

\section{Implications for Monetary Integration}

The implications of the analysis of the estimated impulse-response coefficients that can be established for monetary integration in East Asia are twofold. On one side, if the shape and magnitude of the responses of the endogenous variables to the structural shocks diverge dramatically across the countries, it will become awkward to address all countries economic needs with a one-size-fits-all monetary policy. On the other side, a unified monetary policy can only be effective if the response of the main macroeconomic variables to monetary shocks is similar throughout the whole currency area. In respect to the degree of homogeneity with which each shock affects each endogenous variable, figures 1-9 suggest that the

Figure 9.
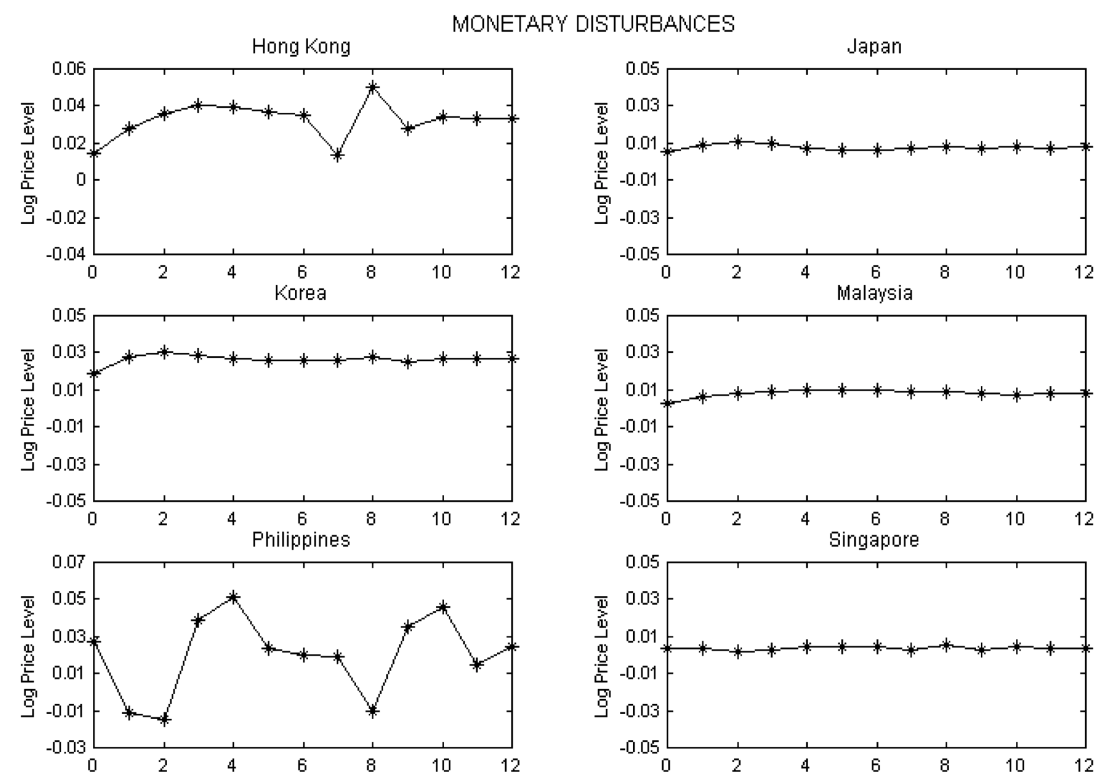
overall pattern of responses is quite similar across the East Asian countries under scrutiny. Perhaps, the only sources of concern relate to the output response to demand shocks and also the fact that the response of the real exchange rate and price level to supply shocks in Korea diverges from that of the remaining countries. In what concerns the effectiveness of a unified monetary policy in reaching-out each country in an evenly fashion, the fact that the shape of the responses of the three endogenous variables to monetary shocks is remarkably similar across every East Asian country looked at, is of extreme significance. That is because it means that unexpected monetary stimuli released by the central monetary authority affect similarly each participating economy. In particular, maintaining stable prices areawide should be facilitated by the fact that the price level responses to monetary disturbances are similar in these East Asian countries.

\section{B. Correlation of Disturbances}

A natural way of examining the relevant issue regarding the degree of symmetry of shocks among countries candidate to form a currency area, is to compute pair-wise correlations of the identified disturbances. However, as pointed out by Bayoumi and Eichengreen (1994), in order to assess the co-movements of shocks it is recommendable to discount the part attributable to the international business cycles in these co-movements. For that purpose, as in Bayoumi and Eichengreen (1994) the correlations between the shocks of the G3 countries (United States, Germany and Japan) are used to compute a critical value that will benchmark the significance of positive correlations. The critical value ensues from noting that the statistic $\mathrm{c}=0.5 \ln [(1+r) /(1-r)]$ follows approximately a normal distribution with mean $0.5 \ln [(1+\rho) /(1-\rho)]$ and variance $(T-3)^{-1}$, where $r$ denotes the estimated correlation coefficient, $\rho$ stands for the null value of the correlation coefficient and $T$ gives the number of observations. To obtain the critical value, it was used the mean of the correlations of each type of shock between the G3 countries as the null value and a significance level of ten percent.

The average correlation among the G3 countries for the three types of disturbances and the correspondent critical values are shown in table 3 in

Table 3. Critical Values

\begin{tabular}{lccc}
\hline & Supply Shocks & Demand Shocks & Monetary Shocks \\
\hline Correlation G3 & -0.1258 & -0.1006 & 0.3904 \\
Critical Values & 0.2247 & 0.2487 & 0.6453 \\
\hline
\end{tabular}


appendix. Tables 4 and 5 in appendix contain the cross-correlations for each structural disturbance for the East Asian and Euro-11 countries, respectively. The

Table 4. East Asia

\begin{tabular}{|c|c|c|c|c|c|c|}
\hline Supply Shocks & Hong Kong & Japan & Korea & Malaysia & Philippines & Singapore \\
\hline Hong Kong & 1 & & & & & \\
\hline Japan & -0.3125 & 1 & & & & \\
\hline Korea & -0.1065 & 0.3765 & 1 & & & \\
\hline Malaysia & 0.2369 & -0.2074 & -0.0627 & 1 & & \\
\hline Philippines & -0.2157 & -0.1258 & -0.1431 & -0.4899 & 1 & \\
\hline Singapore & 0.2492 & -0.2405 & -0.3263 & 0.5171 & 0.1569 & 1 \\
\hline Demand Shocks & Hong Kong & Japan & Korea & Malaysia & Philippines & Singapore \\
\hline Hong Kong & 1 & & & & & \\
\hline Japan & -0.3375 & 1 & & & & \\
\hline Korea & 0.1396 & -0.0901 & 1 & & & \\
\hline Malaysia & -0.0914 & 0.0684 & -0.0317 & 1 & & \\
\hline Philippines & -0.0983 & 0.0527 & -0.3004 & 0.2473 & 1 & \\
\hline Singapore & -0.1653 & -0.4578 & -0.1273 & -0.0054 & 0.2703 & 1 \\
\hline Monetary Shocks & Hong Kong & Japan & Korea & Malaysia & Philippines & Singapore \\
\hline Hong Kong & 1 & & & & & \\
\hline Japan & 0.4675 & 1 & & & & \\
\hline Korea & -0.3664 & -0.5798 & 1 & & & \\
\hline Malaysia & -0.1402 & -0.0942 & 0.1354 & 1 & & \\
\hline Philippines & 0.1107 & -0.0788 & -0.0005 & 0.0534 & 1 & \\
\hline Singapore & 0.0066 & 0.0309 & -0.1193 & 0.3635 & 0.4388 & 1 \\
\hline
\end{tabular}

Table 5. Euro-Zone

\begin{tabular}{|c|c|c|c|c|c|c|c|c|c|c|}
\hline Supply Shocks & Austria & Belgium & Finland & France & Germany & Netherlands & Ireland & Italy & Portugal & Spain \\
\hline Austria & 1 & & & & & & & & & \\
\hline Belgium & -0.1729 & 1 & & & & & & & & \\
\hline Finland & 0.1447 & 0.0755 & 1 & & & & & & & \\
\hline France & 0.2374 & 0.6245 & 0.179 & 1 & & & & & & \\
\hline Germany & 0.0469 & 0.5574 & -0.0302 & 0.6785 & 1 & & & & & \\
\hline Netherlands & -0.0758 & 0.1496 & -0.1607 & 0.114 & 0.6627 & 1 & & & & \\
\hline Ireland & -0.4152 & 0.1512 & 0.1736 & -0.2208 & -0.2035 & -0.1664 & 1 & & & \\
\hline Italy & -0.1179 & 0.8483 & 0.2105 & 0.6996 & 0.6063 & 0.2701 & 0.0996 & 1 & & \\
\hline Portugal & 0.5595 & 0.2959 & 0.0902 & 0.365 & 0.5319 & 0.3379 & -0.2546 & 0.1528 & 1 & \\
\hline Spain & 0.0883 & 0.5455 & 0.0524 & 0.202 & 0.2628 & 0.0953 & 0.209 & 0.4369 & 0.4798 & 1 \\
\hline Demand Shocks & Austria & Belgium & Finland & France & Germany & Netherlands & Ireland & Italy & Portugal & Spain \\
\hline \begin{tabular}{|l|} 
Austria \\
\end{tabular} & 1 & & & & & & & & & \\
\hline Belgium & 0.6412 & 1 & & & & & & & & \\
\hline Finland & 0.4235 & 0.2126 & 1 & & & & & & & \\
\hline France & 0.5878 & 0.6787 & 0.1213 & 1 & & & & & & \\
\hline Germany & 0.8125 & 0.6512 & 0.2899 & 0.5545 & 1 & & & & & \\
\hline Netherlands & 0.7686 & 0.6196 & 0.2746 & 0.3875 & 0.8218 & 1 & & & & \\
\hline Ireland & 0.2956 & 0.1354 & 0.1977 & 0.3678 & 0.3544 & 0.2301 & 1 & & & \\
\hline Italy & -0.1947 & -0.2711 & -0.2101 & -0.4004 & -0.2822 & -0.0968 & -0.1658 & 1 & & \\
\hline Portugal & 0.326 & 0.3944 & 0.097 & 0.2273 & 0.5213 & 0.5511 & 0.3708 & 0.0076 & 1 & \\
\hline Spain & 0.4849 & 0.2834 & 0.4052 & 0.5998 & 0.4107 & 0.3007 & 0.5915 & -0.5865 & 0.3578 & 1 \\
\hline Monetary Shocks & Austria & Belgium & Finland & France & Germany & Netherlands & Ireland & Italy & Portugal & Spain \\
\hline Austria & 1 & & & & & & & & & \\
\hline Belgium & 0.2691 & 1 & & & & & & & & \\
\hline Finland & 0.0187 & 0.152 & 1 & & & & & & & \\
\hline France & 0.24 & 0.3352 & -0.4126 & 1 & & & & & & \\
\hline Germany & 0.1925 & 0.3998 & 0.7408 & -0.0425 & 1 & & & & & \\
\hline Netherlands & 0.0204 & 0.2989 & 0.2164 & -0.1194 & 0.2334 & 1 & & & & \\
\hline Ireland & -0.0635 & 0.3248 & 0.2509 & 0.0304 & -0.0178 & 0.5266 & 1 & & & \\
\hline Italy & 0.0228 & 0.0369 & -0.082 & -0.0229 & 0.1071 & 0.0599 & -0.3218 & 1 & & \\
\hline Portugal & -0.1329 & -0.3287 & 0.115 & 0.1649 & 0.1986 & -0.3226 & 0.0196 & -0.048 & 1 & \\
\hline Spain & 0.3714 & -0.2043 & -0.1036 & 0.2794 & -0.096 & -0.644 & -0.1862 & -0.0484 & 0.3273 & 1 \\
\hline
\end{tabular}


shaded cells denote significant positive correlations. From table 4 it is apparent that more than half of the cross-correlations are negative, which is a situation obviously detrimental to the creation of a currency area. In stark contrast to the Asian situation, the cross-correlations of the supply disturbances among the Euro11 economies paint a much more coherent picture, as the overwhelming majority of correlations are positive. Even though the number of positive cross-correlations of demand disturbances in East Asia is the same as for supply shocks, only one of those is significant. The discrepancy between the number of significant correlations in East Asia and Europe is even greater for the demand shocks. In respect to the cross-correlations of monetary disturbances, the number of positive cells in table 4 is considerable greater than it is the case with supply or demand disturbances, which is mainly picking the higher synchronisation of monetary shocks internationally (i.e. among the G3 countries). Again, monetary disturbances move considerably closer together in the Euro-11 than they do in East Asia.

In face of the evidence presented above it seems that the pattern of crosscorrelations of the structural shocks does not encourage the formation of a currency union in East Asia, at least immediately. However, as the European integration suggests, any realistic chances of successful monetary integration must follow a far-reaching process of gradual economic integration. Thus, East Asian monetary integration should start with the elimination of barriers to the free circulation of commodities, labour and capital and the coordination of policies in order to bring the co-movements of structural shocks closer together.

Finally, it must be noted that the cross-correlations of shocks do not convey any information on how shocks translate into macroeconomic volatility and for how long. Also, the correlation of shocks does not address the issue of whether fiscal and monetary policies are successful in smoothing out the effects of potentially asymmetric structural disturbances. In what follows, these issues are discussed.

\section{Variance Decomposition}

The purpose of computing the variance decompositions is to ascertain the relative importance of each structural disturbance in the fluctuations or variance of each endogenous variable in distinct time frames. More precisely, the variance decomposition for the $\mathrm{k}^{\text {th }}$ year yields the percentual contribution of each structural shock to the variance of the k-year ahead forecast errors of each endogenous variable. Thus, by computing the forecast error variance decomposition for $k=0$, ...., 12, a time-profile of the relative importance of each structural shock in the 
levels of each variable is obtained.

\section{Results}

The results of the variance decomposition for the levels of the three endogenous variables for different time-horizons are reported in table 6 . The numbers in parenthesis are the standard deviation of the countries pertaining to each block.

\section{Real Output}

The overall pattern of the variance decomposition of real output expressed in table 6 conveys the striking result that, contrary to the Keynesian stand on business cycles and in line with the real bussiness cycles tradition. short run fluctuations of output in East Asia and Euro-11 are on average mainly determined by unforeseen supply rather than demand disturbances. This outcome is however in line with that obtained for the United States by Gali (1992) and to some extent for Europe by Erkel-Rousse and Melitz (1995). The fact that the influence of demand and monetary shocks on output fluctuation fades away with time ensues from the long run restriction that both shocks have transitory effects on output. Among demand and monetary shocks, the latter dominates as a source of real output fluctuations, as expected.

Table 6. Averages of Variance Decomposition for Variables in Levels
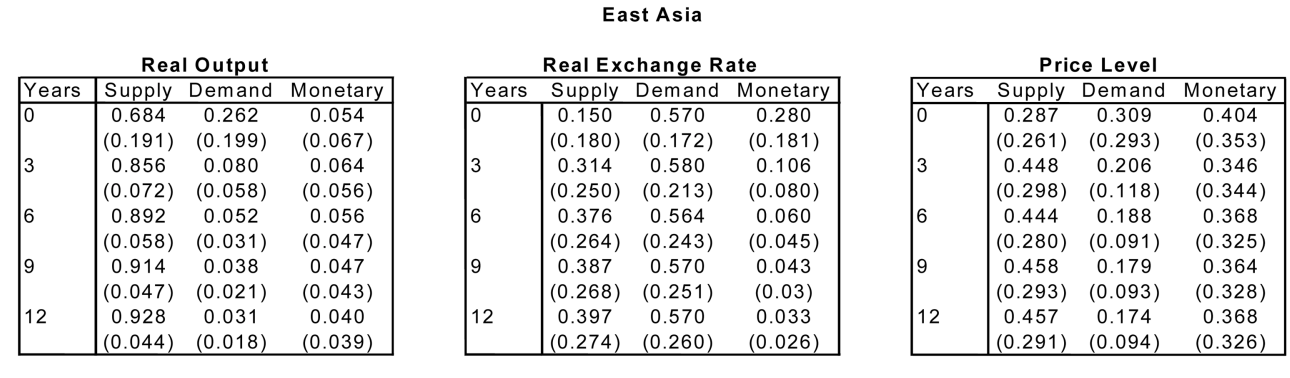

Euro-Zone
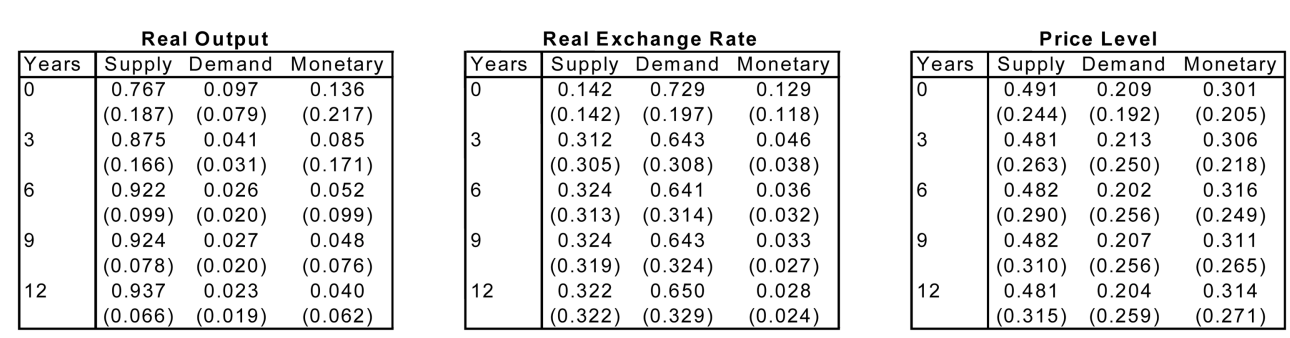


\section{Real Exchange Rate}

A glance at table 6 reveals that for the East Asian countries, demand shocks are the main source of short term variability in the real exchange rate. This result presumably reflects the high degree of openness of these economies, which makes the exchange rate quite sensitive to internal and external demand shocks. Not surprisingly, monetary shocks that encompass capital flows are, on average, the second major force behind real exchange rate volatility in the shorter term. It is interesting to note that as the system approaches the long run, the theoretically imposed fading influence of monetary disturbances in the variance of the real exchange rate materialises almost on a one-to-one increase in the share of supply disturbances, leaving the relative importance of demand shocks remarkably still.

\section{Price Level}

The average contribution for the price levels variance in East Asia in the short run is quite evenly distributed among the structural disturbances, with monetary disturbances with a slight edge over demand and supply shocks. However, as we move towards the longer run, supply shocks become the single major force of variability as the share of the other two shocks dwindles. Contrary to supply and demand shocks, the contribution of monetary shocks to price variability is quite steady for the time-horizons spreading from three to twelve years.

\section{Implications for Monetary Integration in East Asia}

That the impact of different shocks on a specific set of variables differs from country to country is a fact of life. Although that may hinder the smooth functioning of a currency area eventually formed by these Asian countries, the situation is not different from that of a large country, like the United States, where regions necessarily exhibit their own idiosyncrasies in what concerns the response of central economic variables to a diversity of stimuli. Since this study has been using the Euro-11 as benchmark, the implications for monetary integration in East Asia must be drawn from the comparison of the asymmetry of the impact of shocks on the variables' variability between the East Asian and Euro-11 blocks. For that purpose, the standard deviations reported in brackets in table 6 are used. Altogether these estimated standard deviations seem to imply that the impact of each shock on the variables variability is more asymmetric across the Euro-11 members than across the East Asian countries. Most notably is perhaps the fact that the variation across countries of the contribution of the dominant supply 
shocks for real output fluctuations within the 3-6 years time span is significantly higher in Europe than in East Asia. This implies that East Asian economies are arguably more similar than the Euro-11 countries in what concerns structural adjustment to shocks.

As argued by Erkel-Rousse and Melitz (1995), the variance decomposition analysis can be extended to give an insight into the relevance of fiscal policy and also the opportunity cost of relinquishing monetary control after monetary unification. The rationale is straightforward. If demand shocks, through which fiscal policy operates, are sufficiently important in explaining real output variations in the short run, then the retention of fiscal policy instruments provides a relevant stabilising tool able to attenuate the consequences of asymmetric shocks throughout the currency area. On the other hand, if the short-term share of real output fluctuations accounted for monetary disturbances is not extremely significant, the surrender of monetary control entailed by monetary integration does not constitute a major cost since it does not constitute a powerful policy tool in the first place.

It turns out that demand disturbances are a forceful source of real output short run variability in East Asia. In particular, the average contribution of demand disturbances to output variability in the East Asian countries exceed by far that of the European countries, which stands as an additional indication that, bearing on the European experience, monetary integration in East Asia seems rather feasible. Regarding the cost of forsaking monetary policy, it is clear that monetary disturbances play a minute role in explaining the short-term volatility of real output in East Asia. Once again, East Asian countries seem to be in a good position relative to the Euro-11 to engage in monetary integration.

\section{Speed of Adjustment}

The speed at which economies adjust to disturbances constitutes a crucial dimension of the assessment of the desirability of the creation of a currency area. If the deviations that follow the occurrence of a shock are swiftly eliminated, the costs of forsaking monetary policy independence are bound to be smaller even in situations where countries experience asymmetric shocks and divergent responses to those shocks. Apart from the issue of transitory volatility, the speed of convergence towards the long term effect is especially relevant for the shocks with no permanent effects on the long run levels of the endogenous variables, particularly in what refers to real output. 
The speed of adjustment of each endogenous variable after the occurrence of a shock is measured by the response after two years as a share of the long term effect $^{10}$. But in order to facilitate the analysis and allow meaningful comparisons, a more aggregate measure that summarises the speed of adjustment of each country to a particular shock is desirable. Unlike Bayoumi and Eichengreen (1994), who use the average across the endogenous variables of the speeds of adjustment to each shock, the measure of speed of adjustment used here is calculated as the average across variables, of one minus the adjustment remaining ${ }^{11}$ for the impact of each shock. The superiority of the measure devised here relative to the one used by Bayoumi and Eichengreen lies on the fact that depending on the variable, the short term impact of a shock may undershoot or overshoot the overall long term effect. Thus, the calculated values of the speed of adjustment may lie below or above unity, implying that the average is biased towards unity, and so the aggregate measure used by Bayoumi and Eichengreen (1994) is likely to overestimate the speed of convergence towards the long run equilibrium. Table 7 contains the speed of adjustment for the East Asian countries as well as an aggregate measure for East Asia and the Euro-zone countries and reads as follows. In the upper part of the table, each cell yields the proportion of the long run adjustment accomplished in the first two years after the occurrence of a structural shock.

Table 7 reveals the disparity of the speed with which the East Asian economies

Table 7. Speed of Adjustment

(\% of adjustment after 2 years)

\begin{tabular}{lccc}
\hline & Supply Shocks & Demand Shocks & Monetary Shocks \\
\hline Hong Kong & 63.59 & 90.84 & 96.59 \\
Japan & 56.33 & 78.09 & 84.07 \\
Korea & 81.87 & 92.37 & 95.34 \\
Malaysia & 66.74 & 45.8 & 99.32 \\
Philippines & 50.31 & 33.84 & 44.48 \\
Singapore & 71.8 & 92.05 & 81.64 \\
\hline & \multicolumn{3}{|c}{ Average } \\
\hline East Asia & 65.11 & 72.17 & 83.57 \\
Euro-Zone & 50.25 & 66.85 & 91.99 \\
\hline
\end{tabular}

${ }^{10}$ For the responses for which the theoretical identifying restrictions impose convergence towards zero, the measure of the speed of adjustment is computed as one minus the impulse-response after two years.

${ }^{11}$ The adjustment remaining is in turn calculated as the absolute value of one minus the ratio of the response after two years to the long run effect of any particular shock. 
converge to the long run equilibrium. In what concerns the average speeds of adjustment in the Asian countries, it is clear that supply shocks take longer than any other shock to be fully absorbed. Nevertheless, the adjustment accomplished after two years of the occurrence of any shocks well exceeds fifty percent.

In comparison with the Euro-11 block, the Asian countries, on average, adjust faster to supply and demand shocks and slower to monetary shocks. The fact that overall adjustment to shocks is faster in East Asia presumably suggests that East Asian economies have a greater degree of flexibility than the members of the Euro-11, but more importantly, it signifies that the pains of the short-term adjustment for which monetary policy might be useful in alleviating, last shorter in East Asia. Thus, the costs of forsaking control over monetary policy are likely to be lower wherever full-adjustment to shocks is swifter.

\section{Discussion and Conclusions}

The empirical results of the paper suggest the East Asian countries under scrutiny to be in a good position relatively to the Euro-11 economies to pursue monetary integration ${ }^{12}$.

The finding that disturbances are not highly correlated is a reminder that any realistic attempt of successful monetary integration in East Asia requires the implementation of a process of convergence in the lines of those devised in the European Union prior to the launch of the euro. However, unlike Europe, East Asia does not have serious antecedents of co-operation at the supranational level and the few initiatives of formal integration have struggled to even agree an agenda let alone implementing concrete co-ordinated policies. This situation clearly contrasts with the path of integration followed by European countries after the World War II, where the debate over monetary integration has gone in tandem with discussions of political integration and the creation of supranational institutions (Eichengreen and Bayoumi, 1996).

An additional source of complexity towards the formation of a currency area in East Asian lies on the high level of diversity patent in the region. Economically, East Asia is far more heterogeneous than the Euro 11 countries, not only in terms degree of economic and financial development, but also in terms of growth rates,

\footnotetext{
${ }^{12}$ However, the interpretation of these results should take into the account the possibility the absence of some East Asian countries due to data limitations is introducing a selection bias.
} 
interest rates, government debt levels, just to mention some important macroeconomic indicators. Moreover, the balance of economic power in East Asia is tilted in favour of Japan in a way that does not find parallel in the Euro zone. Adding this to the international status of the Japanese currency, it becomes obvious that any attempt of monetary integration in East Asia the depend on Japan's stand on the issue. On the political sphere, East Asia hosts systems that range from communism in China to authoritarian capitalism in Malaysia and democratic capitalism in Japan. The contrast is even starker at the cultural level, as East Asia hosts all the major religions in the world and it is home to a wide ethnic variety. East Asian cultural heterogeneity even extends to much broader categories, like consumption behaviour and business practices. The high heterogeneity of the East Asian region necessarily hinders formal integration of any kind, even though it nurtures informal integration (Peng, 2000). This is because, where diversity constitutes an obstacle to formal integration it implies the existence of economic complementarity that forges the ideal conditions for a regional division of labour that is at the root of informal integration in East Asia. But, as argued by Peng it is not straightforward that intensifying informal integration eventually leads to formal integration.

In spite of the paramount importance of regional factors, a full appraisal of the overall feasibility of monetary integration should be taken beyond the regional level to contemplate the incentives and constraints posed by the global order (Henning, 1998). When embedded in a broader, international context, the issue of economic integration cannot be detached from the increasing interdependence of the world economy nor from the wave of regionalism that is sweeping across the planet. In this context, and as the nation-state loses power and sovereignty as historically defined since the Modern Age, monetary integration could be also seen at the light of a collective, regional struggle for re-gaining power and influence. This view is corroborated by the point made by Streeck and Schmitter (1991, p.148) according to which the renewed momentum of integration in Europe in the 1980s can be explained as a move aimed at restoring some of the economic and political sovereignty lost to the United States and Japan. A parallel could arguably be established to East Asia by which the emergence of a new order that obfuscates individual nations provides strategic incentives that add to the economic benefits of monetary integration. In the same manner as Europe's fading influence in the world's scene fostered the European integration process, the Asian crisis of 1997-98 by bluntly illustrating the vulnerability of the regions individual nation-states might have helped nudging the case for further formal integration. In 
that sense, monetary integration in East Asia can be seen as the constitution of a political cartel with which East Asian governments can still carve out collectively, if only partially, their own destinies.

In summary, there seems to be an economic case for monetary integration in East Asia based on the empirical results of presented in section IV and also on the potential considerable benefits that would accrue from currency unification in a region becoming increasingly economically integrated. The emergence of a global economy that dilutes national sovereignty and influence and nurtures the formation of regional blocs also provides an additional incentive for further formal integration in East Asia. However, the existence of numerous factors entrenched in East Asian reality that stand in the way of formal integration implies that monetary integration rests on the perceived net benefits being enough to compel East Asian countries to compromise on a wide range of issues that still set them apart. Whether monetary integration will occur in a foreseeable future will depend on how East Asian economics and politics evolve together and also on how the geometry of the rest of the world shapes up.

\section{Acnowledgements}

I am indebted to Somnath Sen, Peter Sinclair, Michael Artis, Jayasri Dutta, Robert Taylor and an anonymous referee for useful comments and suggestions. Financial support from Fundação para a Ciência e Tecnologia under grant BD/11289/97 is gratefully acknowledged.

Received 8 May 2002, Accepted 18 October 2002

\section{References}

Ayat, L., Burridge, P. (2000) Unit Root Tests in the Presence of Uncertainty About the Non-Stochastic Trend, Journal of Econometrics, 95, 71-96.

Balassa, B. (1964) The Purchasing-power Parity Doctrine: A Reappraisal, Journal of Political Economy, 62, 584-96.

Bayoumi, T., Eichengreen, B. (1994) One Money or Many? Analyzing the Prospects for Monetary Unification in Various Parts of the World, Princeton Studies in International Finance, 76.

Benassy-Querre, A. (1996) Exchange Rate Regimes and Policies in Asia, Centre for International and Development Economics Research, Working Paper C96-081, 
University of California at Berkeley.

Blanchard, O., Quah, D. (1989) The Dynamic Effects of Aggregate Demand and Supply Disturbances, American Economic Review, 79, 655-73.

Clarida, R., Gali, J. (1994) Sources of Real Exchange rate Fluctuations: How Important are Nominal Shocks?, The Carnegie-Rochester Conference Series on Public Policy, December 1-55.

Eichengreen, B., Bayoumi, T. (1996) Is Asia an Optimum Currency Area? Can It Become One? Regional, Global and Historical Perspectives on Asian Monetary Relations, Centre for International and Development Economics Research, University of California at Berkeley, Working Paper No. C96-081.

Erkel-Rousse, H., Melitz, J. (1995) New Empirical Evidence on the Costs of European Monetary Union, CEPR Discussion Paper No.1169.

Frankel, J. (1991) Is a yen Bloc Forming in Pacific Area?", in Finance and The International Economy, 5: The AMEX Bank Review Prize Essays, (Ed.) R. OBrien, Oxford: Oxford University Press, 4-20.

Gali, J. (1992) How Well Does the IS-LM Model Fit Postwar US Data?, Quarterly Journal of Economics, 107, 709-38.

Goto, J., Hamada, K. (1994) Economic Preconditions for Asian regional Integration, in Macroeconomic Linkage: Savings, Exchange Rate and Capital Flows, (Ed.) Ito, T., Krueger, A., Chicago: Chicago University Press.

Henning, C. (1998), Systemic Conflict and Regional Monetary Integration: The Case of Europe, International Organization, 52, 537-573.

Johansen, S. (1988) Statistical Analysis of Cointegration Vectors, Journal of Economic Dynamics and Control, 12, 231-54.

Obstfeld, M. (1985) Floating Exchange Rates: Experience and Prospects, Brooking Papers on Economic Activity, 2, 369-450.

Peng, D. (2000), The Changing Nature of East Asia as an Economic Region, Pacific Affairs, 73, 171-91.

Samuelson, P. (1964) Theoretical Notes on Trade Problems, Review of Economics and Statistics, 46, 145-54.

Streeck, W. and P. Schmitter (1991), From National Corporatism to Transnational Pluralism: Organised Interests in the Single European Market, Politics and Society, 19, 133-63. 